(c) American Dairy Science Association, 2005.

\title{
Effect of Body Fatness and Glucogenic Supplement on Lipid and Protein Mobilization and Plasma Leptin in Dairy Cows
}

\author{
T. Kokkonen, ${ }^{1}$ J. Taponen, ${ }^{2}$ T. Anttila, ${ }^{1}$ L. Syrjälä-Qvist, ${ }^{1}$ C. Delavaud, ${ }^{3}$ \\ Y. Chilliard, ${ }^{3}$ M. Tuori, ${ }^{1}$ and A. T. Tesfa ${ }^{1, *}$ \\ ${ }^{1}$ Department of Animal Science, P.O. Box 28, 00014 University of Helsinki, Finland \\ ${ }^{2}$ Department of Clinical Veterinary Medicine, University of Helsinki, Pohjoinen pikatie 800, \\ 04920 Saarentaus, Finland \\ ${ }^{3}$ Herbivore Research Unit, INRA, Theix-63122, St-Genes Champanelle, France
}

\begin{abstract}
Twenty-four multiparous Ayrshire cows were used in an experiment to test the effect of body fatness and glucogenic supplement, fed during the transition period, on lipid and protein mobilization and plasma hormone concentrations. Eight weeks before their expected calving date, the cows were divided into blocks of 4 . Two cows with the highest body condition score within each block were then allocated to a test (T) group and the other 2 cows to a control (C) group. To scale up the differences between fatter and thinner cows, the estimated energy allowance was $40 \%$ higher in group $\mathrm{T}$ than in group $\mathrm{C}$ between $\mathrm{d} 56$ and 21 prepartum. For the final 3 wk before calving, all the cows were fed according to energy recommendations for pregnant cows. Within $\mathrm{C}$ and $\mathrm{T}$ groups and blocks, cows were randomly assigned into groups with (G1) or without (G0) glucogenic supplement. Division to G0 and G1 groups was made 2 wk before the expected calving and continued for $56 \mathrm{~d}$ postpartum. After calving, all the cows received grass silage ad libitum and a common daily concentrate allowance. No significant differences were detected in feed intake and milk yield between $\mathrm{C}$ and $\mathrm{T}$. The T groups showed an earlier rise of nonesterified fatty acids as calving approached and had higher plasma nonesterified fatty acids during the final week of pregnancy and lactation wk 1 to 3 . At the same time, adipose tissue samples from fatter cows tended to show higher in vitro lipolytic responses to added norepinephrine, as monitored by glycerol release. Protein mobilization was elevated during the final week of pregnancy and tended to be more increased in fatter cows. Glucogenic supplement did not decrease lipid or protein mobilization. Fatter cows had higher plasma leptin concen-
\end{abstract}

Received January 9, 2004.

Accepted December 10, 2004.

Corresponding author: Tuomo Kokkonen; e-mail: tuomo. kokkonen@helsinki.fi.

*Current address: National Veterinary and Food Research Institute (EELA), P.O. Box 45, 00581 Helsinki, Finland. tration prepartum, showed a more pronounced decrease in leptin concentration near calving, and had higher plasma leptin concentration after calving. In conclusion, fatter cows initiated more extensive mobilization of body fat before calving and this continued during the first lactation weeks. Plasma leptin concentration in early-lactation cows was associated with body fatness and not with estimated energy balance.

(Key words: dairy cow, body fatness, lipid mobilization, leptin)

Abbreviation key: 3-MH = 3-methylhistidine, $\mathbf{C}=$ control group, $\mathbf{E B}=$ energy balance, $\mathbf{E C M}=$ energycorrected milk yield, $\mathbf{F D}=$ fat depth, $\mathbf{G 0}=$ no glucogenic supplement, $\mathbf{G 1}$ = with glucogenic supplement, $\mathbf{M E}=$ metabolizable energy, $\mathbf{T}=$ test group.

\section{INTRODUCTION}

After parturition, dairy cows' feed intake lags behind milk yield, and tissue mobilization of lipids and amino acids is a key factor in enabling the transition from pregnancy to lactation. Lipolysis increases the NEFA concentration in blood, resulting in increased fatty acid uptake by the liver. Due to the limited capacity of ruminants for exporting triglycerides in very low density lipoproteins, lipid accumulation in the liver is increased, which may negatively affect ureagenesis, gluconeogenesis, and clearance of endotoxins and hormones (Rukkwamsuk et al., 1999). Fat cows may be particularly susceptible to lipid accumulation if they have lower feed intake or higher milk yield and more pronounced lipid mobilization than leaner cows, as suggested by earlier studies (Garnsworthy and Topps, 1982; Treacher et al., 1986; Chilliard, 1992). The lipolytic response of adipose tissue in overfed cows may differ from that of normal cows (Rukkwamsuk et al., 1998).

The supply of glucose precursors affects the fate of fatty acids in liver. When the supply of propionate, glucogenic amino acids, lactate, and glycerol decreases, 
a greater proportion of acetyl coenzyme A ends up in ketogenesis as a glucose-sparing mechanism (Rukkwamsuk et al., 1999). Decreased feed intake and thereby lowered propionate production in the rumen, in connection with increased NEFA supply to the liver, probably accounts for the increased risk of ketosis in overconditioned cows (Rukkwamsuk et al., 1999). Glucogenic supplementation may decrease ketone formation directly by increasing complete oxidation of NEFA or indirectly by decreasing mobilization of NEFA via elevated blood insulin or increased fatty acid re-esterification in adipose tissue (Burhans and Bell, 1998).

Bell et al. (2000) suggested that a high-yielding dairy cow might mobilize as much as $1000 \mathrm{~g}$ of tissue protein per day for the first 7 to $10 \mathrm{~d}$ of lactation. In underfed dairy cows, protein mobilization from skeletal muscles may account for $50 \%$ of the total protein mobilization (Chilliard and Robelin, 1983). The net contribution of amino acid mobilization to glucose production is considerably smaller than total mobilization as a result of increased milk protein synthesis, and increases in protein synthesis in the liver and digestive tract may mask, in part, mobilization of amino acids from muscles (Chilliard, 1999).

Several hormones control metabolic adaptation during the transition period. Based on the evidence from other species (human, rat, sheep), leptin may play an important role during this adaptation period by coordinating feed intake, energy expenditure, and tissue nutrient use (Ingvartsen and Boisclair, 2001). Leptin may have an autocrine/paracrine effect on inhibition of lipogenesis and stimulation of lipolysis. The degree of body fatness explains a large part of the variation in plasma leptin concentrations in sheep and cattle (Chilliard et al., 2001). Block et al. (2001) reported that the decrease in plasma leptin near parturition coincides with the onset of negative energy balance (EB) induced by the initiation of copious milk secretion.

The objective of the present experiment was to study the effects of body fatness on lipid and amino acid mobilization and on plasma leptin concentrations. Furthermore, we studied the lipolytic response of adipose tissue during the periparturient period. We also studied the effect of glucogenic supplementation on tissue mobilization and ketogenesis.

\section{MATERIALS AND METHODS}

\section{Animals and Experimental Design}

Twenty-four multiparous Ayrshire cows that calved between October 20, 2000 and February 6, 2001, were used in a randomized complete block design with treatments in a $2 \times 2$ factorial arrangement. The experimental factors were normal (control, C) or increased (test,
T) body fatness during the dry period, and glucogenic supplement ( 0 vs. $1 \mathrm{~kg} / \mathrm{d}$; G0 and G1) from $14 \mathrm{~d}$ before the expected calving date to $56 \mathrm{~d}$ after calving. The cows were dried off from the lactation preceding this trial approximately $9 \mathrm{wk}$ before the predicted date of calving. Eight weeks before their expected calving date, the cows were divided into blocks of 4 according to their expected calving dates. The 2 cows with the highest BCS within each block were then allotted to the T group and the 2 cows with lower BCS were allotted to the C group. Within each body condition group and block, the cows were randomly assigned to glucogenic supplement groups.

The deliberate allocation of cows with the highest BCS within each block to the T group was based on the assumption that relatively more nutrients are deposited in tissues during late lactation than during the dry period, and that initial differences in body fatness were due to differences in feed intake during late lactation. Our aim was to scale up the differences between fatter and thinner cows. However, it must be noted that higher initial BCS may include a genetic predisposition toward fatness in addition to differing nutritional histories of the animals.

\section{Feeds and Feeding}

The feeding plan is summarized in Table 1 . Between d 56 and 21 prepartum, the cows in group $\mathrm{C}$ were fed individually according to energy recommendations ( $\mathrm{Tu}$ ori et al., 2000). The metabolizable energy (ME) requirement for maintenance was calculated according to MAFF (1975): $(8.3+0.091 \times \mathrm{BW})$ and an additional allowance of $18.7 \mathrm{MJ} / \mathrm{d}$ was made for pregnancy. The target ME allowance for cows in group T was $34 \mathrm{MJ} / \mathrm{d}$ over the MAFF recommendation. The additional energy is equivalent to the requirement for $1 \mathrm{~kg} / \mathrm{d} \mathrm{BW}$ gain (MAFF, 1975). Average feed allowances and chemical composition of the diets between $\mathrm{d} 56$ and 21 prepartum are shown in Table 2. Based on feed analyses, the actual difference in $\mathrm{ME}$ allowances (38 MJ/d) between the $\mathrm{C}$ and $\mathrm{T}$ groups was somewhat larger than intended.

For the final 3 wk before calving (lead feeding), all cows were fed according to the energy recommendation for pregnant cows (Tuori et al., 2000; Table 1). The ME requirement for maintenance was calculated as above and an additional allowance of $34 \mathrm{MJ} / \mathrm{d}$ was made for pregnancy. In addition to the restricted amount of wilted grass silage, the cows received a mixture of barley and oats. The quantity of cereal mixture was increased from an initial amount of $2 \mathrm{~kg} / \mathrm{d}$ to $3 \mathrm{~kg} / \mathrm{d}$ one week before calving. During the final 2 wk of pregnancy, $1 \mathrm{~kg} / \mathrm{d}$ of molassed sugar beet pulp (G0) or $1 \mathrm{~kg} / \mathrm{d}$ of glucogenic supplement (G1) was added to the cereal 
Table 1. Experimental feeding plan.

\begin{tabular}{|c|c|c|c|c|}
\hline \multirow[b]{3}{*}{ Period } & \multicolumn{4}{|c|}{ Treatment $^{1}$} \\
\hline & \multicolumn{2}{|c|}{ Control } & \multicolumn{2}{|c|}{ Test } \\
\hline & G0 & G1 & G0 & G1 \\
\hline $56 \mathrm{~d}$ to $21 \mathrm{~d}$ prepartum ${ }^{2}$ & $\begin{array}{l}\text { Acc } \\
\text { Res }\end{array}$ & $\begin{array}{l}\text { on: } \\
+1 \text { to } 2 \mathrm{~kg} / \mathrm{d} \text { oat straw }\end{array}$ & $\begin{array}{l}\text { Ene } \\
\text { Rest }\end{array}$ & $\begin{array}{l}\text { E/d: } \\
1 \text { to } 2 \mathrm{~kg} / \mathrm{d} \text { compound feed }\end{array}$ \\
\hline $21 \mathrm{~d}$ to $14 \mathrm{~d}$ prepartum ${ }^{2}$ & \multicolumn{4}{|c|}{$\begin{array}{l}\text { According to energy recommendation: } \\
\text { Restricted amount of grass silage }+2 \mathrm{~kg} / \mathrm{d} \text { mixture of barley and oats }\end{array}$} \\
\hline $14 \mathrm{~d}_{\text {prepartum to calving }}{ }^{2}$ & \multicolumn{4}{|c|}{$\begin{array}{l}\text { According to energy recommendation: } \\
\text { Restricted amount of grass silage }+2 \mathrm{~kg} / \mathrm{d} \text { mixture of barley and oats (increased to } 3 \mathrm{~kg} / \mathrm{d} \text { during the final week prepartum) } \\
+1 \mathrm{~kg} / \mathrm{d} \mathrm{MSBP}^{3} \\
\qquad 1 \mathrm{~kg} / \mathrm{d} \mathrm{GS}^{4}\end{array}$} \\
\hline Calving to $56 \mathrm{~d}_{\text {postpartum }}^{5}$ & \multicolumn{4}{|c|}{$\begin{array}{l}\text { Grass silage ad libitum + concentrate mixture }{ }^{6} \text { increased to } 14 \mathrm{~kg} / \mathrm{d} \text { in } 16 \mathrm{~d} \\
+1 \mathrm{~kg} / \mathrm{d} \text { MSBP } \\
\begin{array}{llll}1 \mathrm{~kg} / \mathrm{d} \text { GS } & +1 \mathrm{~kg} / \mathrm{d} \mathrm{MSBP} & +1 \mathrm{~kg} / \mathrm{d} \mathrm{GS}\end{array}\end{array}$} \\
\hline
\end{tabular}

${ }^{1}$ Control = normal body fatness; Test = increased body fatness; G0 = no glucogenic supplement; G1 = glucogenic supplement (1 kg/d) between d 14 prepartum and d 56 postpartum.

${ }^{2} \mathrm{~A}$ mineral mix $(7.7 \% \mathrm{Ca}, 6.4 \% \mathrm{P}, 2.9 \% \mathrm{Mg}, 3.5 \% \mathrm{Na}, 15 \mathrm{kIU} / 100 \mathrm{~g}$ vitamin $\mathrm{A}, 3 \mathrm{kIU} / 100 \mathrm{~g}$ vitamin $\mathrm{D}, 45 \mathrm{mg} / 100 \mathrm{~g}$ vitamin E) was distributed with the cereal mixture at a rate of $100 \mathrm{~g} / \mathrm{d}$.

${ }^{3} \mathrm{MSBP}=$ Molassed sugar beet pulp.

${ }^{4} \mathrm{GS}=$ Glucogenic supplement

${ }^{5} \mathrm{~A}$ mineral mix $(7.5 \% \mathrm{Ca}, 4.0 \% \mathrm{P}, 5.6 \% \mathrm{Mg}, 5.1 \% \mathrm{Na}, 15 \mathrm{kIU} / 100 \mathrm{~g}$ vitamin $\mathrm{A}, 3 \mathrm{kIU} / 100 \mathrm{~g}$ vitamin $\mathrm{D}, 45 \mathrm{mg} / 100 \mathrm{~g}$ vitamin E) was distributed with the concentrate mixture t a rate of $300 \mathrm{~g} / \mathrm{d}$

${ }^{6}$ Mixture of barley, oats, molassed sugar beet pulp, and rapeseed meal. 
Table 2. Average feed allowances and chemical composition of the diets between d 56 to 21 prepartum.

\begin{tabular}{lcc}
\hline & \multicolumn{2}{c}{ Treatment $^{1}$} \\
\cline { 2 - 3 } & Control & Test \\
\hline Feed allowances & & \\
Silage, kg of DM/d & 7.9 & 10.2 \\
Straw, kg of DM/d & 0.3 & 0 \\
Compound feed, kg of DM/d & 0 & 1.3 \\
Mineral supplement, kg of DM/d & 0.09 & 0.09 \\
Total DMI, kg/d & 8.3 & 11.6 \\
ME, ${ }^{2}$ MJ/d & 82 & 120 \\
Chemical composition & 333 & 378 \\
DM, g/kg & 76 & 76 \\
Ash, g/kg of DM & 145 & 153 \\
CP, g/kg of DM & 572 & 529 \\
NDF, g/kg of DM & 323 & 292 \\
ADF, g/kg of DM &
\end{tabular}

${ }^{1}$ Control $=$ normal body fatness; Test $=$ increased body fatness.

${ }^{2} \mathrm{ME}=$ Metabolizable energy.

mixture. Average feed intake between $d 14$ and 1 prepartum is shown in Table 3, and the chemical composition of the feeds given between 3 wk prepartum and 8 wk postpartum is shown in Table 4.

After calving, division into G0 and G1 groups was maintained. Cows were given a concentrate mixture formulated from barley (30\%), oats (30\%), molassed sugar beet pulp (15\%), and rapeseed meal (25\%). In the G1 groups, $1 \mathrm{~kg}$ of molassed sugar beet pulp was replaced by glucogenic supplement (Table 1). The daily concentrate allowance of $15 \mathrm{~kg} / \mathrm{d}$ was achieved within $16 \mathrm{~d}$ after calving. Thereafter, the concentrate allowance remained fixed until the end of the experiment. Until d 4 of lactation, the concentrate was fed 3 times per day (at 0500, 1400, and $2000 \mathrm{~h}$ ), and thereafter 6 times per day (at 0500,0800,1100,1400, 1700, and $2000 \mathrm{~h})$. All cows were offered wilted grass silage ad libitum (same silage as before calving). The silage was distributed by an automated feeding car 5 times per day ( $0530 \mathrm{~h}$ and 4 times between 1430 and $2000 \mathrm{~h}$ ).

Table 3. Average feed intake during lead feeding (last 2 wk before calving).

\begin{tabular}{lllllll}
\hline & \multicolumn{4}{c}{ Treatment $^{1}$} \\
\cline { 2 - 3 } & \multicolumn{2}{c}{ Control } & & \multicolumn{2}{c}{ Test } & \\
\cline { 2 - 3 } \cline { 5 - 6 } & G0 & G1 & & G0 & G1 & SEM \\
\hline Silage DMI, kg/d & 6.0 & 6.1 & & 6.7 & 6.5 & 0.35 \\
Concentrate DMI, kg/d & 3.2 & 3.1 & & 2.9 & 2.9 & 0.16 \\
Total DMI, kg/d & 9.1 & 9.1 & & 9.6 & 9.4 & 0.29 \\
\hline
\end{tabular}

\footnotetext{
${ }^{1}$ Control = normal body fatness; Test = increased body fatness; G0 = no glucogenic supplement; G1 = glucogenic supplement $(1 \mathrm{~kg} /$ d) between d 14 prepartum and d 56 postpartum.
}

\section{Sampling, Chemical Analysis, and Measurements}

Feed offered and feed refused were recorded daily. The feeds were sampled weekly, and the cereal concentrate and silage samples were pooled to form a monthly sample. Samples of molassed sugar beet pulp, glucogenic supplement, and rapeseed meal were pooled to form a 2-mo sample. Feed samples were analyzed as described by Kokkonen et al. (2000; 2002).

The cows were kept in tie stalls and milked twice daily, and the milk yield was recorded for every milking. The milk samples were taken on 4 consecutive milkings at $1,2,4,6,8$, and $10 \mathrm{wk}$ after parturition. The samples were sent to a commercial laboratory (Valio Ltd., Helsinki, Finland) for analysis of fat, protein, lactose, and urea using infrared procedures (MilkoScan FT6000; Foss Electric, Hillerød, Denmark).

Body weights were recorded on 2 consecutive days 3 wk before the expected calving date, at the day of calving, the following day, and at 1, 2, 4, 6 and 8 wk after calving. To minimize the influence of milking and feeding, the cows were always weighed at the same time of day, before the afternoon feeding. Body condition scoring (5-point scale; Edmonson et al., 1989) was done by the same person throughout the experiment in conjunction with weighing.

Changes in body fat reserves and muscular volume were measured with ultrasonographic scanning. A realtime B-mode ultrasound scanner (Aloka SSD-210DXII, Aloka Co. Ltd., Tokyo, Japan) equipped with a 5.0-MHz linear array transducer for measurements of muscle and a 7.5-MHz transducer for measurements of subcutaneous fat was used. Subcutaneous fat depths (FD) were measured at 3 locations as follows: 1) on the left transversal process of the fourth lumbar vertebra, 2 to $3 \mathrm{~cm}$ medially from the lateral end, 2) in the middle of the line connecting the ventral corner of the left tuber coxae and the dorsal tuberosity of the left tuber ischiadicum, and 3) on the same line, $8 \mathrm{~cm}$ cranially from the dorsal tuberosity of the tuber ischiadicum. In addition to the subcutaneous tissue, the entire skin layer was included in the measurements. The changes in muscular volume were followed with measurements of the diameter of the longissimus lumborum muscle. The muscle was scanned on the left transversal process of the fourth lumbar vertebra and the largest diameter measured from membrane to membrane. The measurements were performed 5 times: 2 mo before and $7 \pm 1$ $\mathrm{d}$ before the expected calving day, within $24 \mathrm{~h}$ after parturition, and $7 \pm 1$ and $28 \pm 2 \mathrm{~d}$ after parturition.

Adipose tissue samples were taken at $7 \pm 1 \mathrm{~d}$ before the expected calving day, within $24 \mathrm{~h}$ after parturition, $7 \pm 1$ and $28 \pm 2 \mathrm{~d}$ after parturition. The biopsy specimen was taken from the subcutaneous fat in the area of the 
Table 4. Chemical composition and feeding value of feeds from 3 wk prepartum to 8 wk postpartum.

\begin{tabular}{lccccc}
\hline & $\begin{array}{c}\text { Grass } \\
\text { silage }^{1}\end{array}$ & $\begin{array}{c}\text { Cereal } \\
\text { mixture }^{2}\end{array}$ & $\begin{array}{c}\text { Glucogenic } \\
\text { supplement }^{3}\end{array}$ & $\begin{array}{c}\text { Molassed sugar } \\
\text { beet pulp }\end{array}$ & $\begin{array}{c}\text { Rapeseed } \\
\text { meal }\end{array}$ \\
\hline $\mathrm{n}$ & 6 & 6 & 3 & 3 & 3 \\
$\mathrm{DM}, \mathrm{g} / \mathrm{kg}$ & 221 & 878 & 836 & 876 & 895 \\
$\mathrm{Ash}, \mathrm{g} / \mathrm{kg}$ of DM & 73 & 31 & 66 & 73 & 76 \\
$\mathrm{CP}, \mathrm{g} / \mathrm{kg}$ of DM & 159 & 147 & 125 & 109 & 374 \\
$\mathrm{NDF}$, g/kg of DM & 527 & 267 & 337 & 319 & 264 \\
$\mathrm{ADF}$, g/kg of DM & 302 & 95 & 158 & 192 & 182 \\
$\mathrm{ME},{ }^{4}$ MJ/kg of DM & 10.8 & 12.6 & 13.0 & 12.1 & 11.6 \\
\hline
\end{tabular}

${ }^{1}$ Fermentation quality of grass silage: $\mathrm{pH} 4.0$, soluble $\mathrm{N} 645 \mathrm{~g} / \mathrm{kg}$ of N, $\mathrm{NH}_{3}-\mathrm{N} 120 \mathrm{~g} / \mathrm{kg}$ of N, water-soluble carbohydrates $60 \mathrm{~g} / \mathrm{kg}$ of DM, lactic acid $47 \mathrm{~g} / \mathrm{kg}$ of DM, acetic acid $18 \mathrm{~g} / \mathrm{kg}$ of DM, 0.4 butyric acid g/kg of $\mathrm{DM}$; OM in vitro cellulase digestibility of grass silage, $72.8 \%$.

${ }^{2}$ Mixture of barley and oats (50:50).

${ }^{3}$ Glucogenic supplement (Acetona Energy, Suomen Rehu Oy, Helsinki, Finland) consisted of molassed sugar beet pulp (41\%), lucerne meal (15\%), heat-moisture-, and expander-treated wheat (14\%), wheat bran (14\%), vegetable oil (1\%), and premix (15\%). From the premix, the intake of propylene glycol was $120 \mathrm{~g} / \mathrm{d}$, xylitol $8.7 \mathrm{~g} / \mathrm{d}$, other polyols (mainly arabinitol) $5.3 \mathrm{~g} / \mathrm{d}$, nicotinamide $1 \mathrm{~g} / \mathrm{d}$, and choline chloride $700 \mathrm{mg} / \mathrm{d}$.

${ }^{4} \mathrm{ME}=$ Metabolizable energy.

ischiorectal fossa, several centimeters caudally from the sacrotuberous ligament, from the left and right side in turn. Epidural anesthesia was performed with 120 $\mathrm{mg}$ of lidocaine hydrochloride (Lidocain $20 \mathrm{mg} / \mathrm{mL}$; Orion Corporation, Espoo, Finland). The region was shaved and washed with soap and disinfectant. A stick incision, about $1 \mathrm{~cm}$ in length, was made with a scalpel. Adipose tissue was harvested with a Weil-Blakesley rongeur approximately 20 to 30 times; $2 \mathrm{~g}$ of tissue were needed. No further suturing or antibiotic therapy was used.

Adipose tissue fragments were submerged in KrebsRinger buffer (Sigma Chemical Co., St. Louis, MO), supplemented with $\mathrm{NaHCO}_{3}$ (Sigma) $(15 \mathrm{mmol} / \mathrm{L})$, and with $\mathrm{CaCl}_{2}(2.5 \mathrm{mmol} / \mathrm{L})$. The tubes containing buffer and tissue samples were maintained at $37^{\circ} \mathrm{C}$ and were transported to the laboratory. The tissue fragments were freed as much as possible from the vascular and connective tissue on a glass plate maintained at $37^{\circ} \mathrm{C}$ with a water bath underneath. The tissue was cut into pieces of 10 to $30 \mathrm{mg}$, and about $100 \mathrm{mg}$ of tissue were incubated in $3 \mathrm{~mL}$ of Krebs-Ringer buffer supplemented with $\mathrm{NaHCO}_{3}$ as described above plus $3 \%$ (wt/vol) BSA [Fraction V (fatty acid-free), Roche Diagnostics GmbH, Mannheim, Germany]. Incubation tubes $(10 \mathrm{~mL})$ were gassed with $\mathrm{O}_{2}: \mathrm{CO}_{2}$ (19:1) and capped. All incubations were carried out in duplicate with shaking (150 oscillations $/ \mathrm{min}$ ) at $37^{\circ} \mathrm{C}$. After $15 \mathrm{~min}$, a $1-\mathrm{mL}$ sample of the incubation medium was withdrawn for zero-time analysis. In addition to basal lipolytic rate, the effect of agonist was studied; the agonists used were $50 \mu \mathrm{mol} /$ $\mathrm{L}$ norepinephrine (arterenol, Sigma) and $10 \mathrm{mmol} / \mathrm{L}$ glucose (Sigma). After the zero sample and addition of agonists, the tubes were gassed, capped, and incubated for $120 \mathrm{~min}$. The incubations were stopped by placing the tubes on ice for $5 \mathrm{~min}$ and a $1-\mathrm{mL}$ sample was withdrawn for analysis. Samples taken from the incubation media were stored at $-80^{\circ} \mathrm{C}$ until analysis. The incubation tubes containing the tissue fragments and approximately $1 \mathrm{~mL}$ of incubation media were weighed and placed at $102^{\circ} \mathrm{C}$ for $24 \mathrm{~h}$ to determine the DM content of the tissue sample. The DM content of the incubation media was determined separately and was taken into account in the calculation of tissue DM content.

Lipolysis was monitored by following the release of glycerol, which was assayed with the GPO-Trinder method (McGowan et al., 1983; procedure no. 337; Sigma Diagnostics, Inc., St. Louis, MO) with the following modifications: reagent $A$ was diluted with deionized water (1:1) and the sample and reagent volumes were 10 and $150 \mu \mathrm{L}$, respectively.

Blood samples from the mammary vein (vena subcutanea abdominis) were taken before the afternoon feeding at $1300 \mathrm{~h}$ (Kokkonen et al., 2000). The preplanned schedule for prepartum sampling was $21,7,5,3$, and $1 \mathrm{~d}$ before the expected calving date. If calving was delayed, sampling was continued every second day until calving. The samples taken at $21 \mathrm{~d}$ before the expected calving date and during the final week before the actual calving were used to determine prepartum blood composition. The interval between blood sampling at $21 \mathrm{~d}$ before the expected calving date and the actual calving averaged $23 \mathrm{~d}$ (range 13 to $37 \mathrm{~d}$ ). Due to untimely calving, blood samples from some cows could not be taken in the final week before the calving. In the treatment group CG1, 3 of 4 samples were missing from one cow. In the treatment group TG0, 2 samples were missing from 2 cows. In the treatment group TG1, all 4 samples were missing from one cow, and 1 sample was 
missing from one cow. After calving, the blood samples were taken at $1,3,5,7,14,21,28$, and $56 \mathrm{~d}$ postpartum.

$\beta$-Hydroxybutyrate (Hansen and Freier, 1978) was determined from whole blood. Plasma glucose and NEFA were determined with the methods described by Kokkonen et al. (2000). Plasma creatinine was analyzed with the method of Fabiny and Ertigshausen (1971). Plasma 3-methylhistidine (3-MH) concentrations were analyzed with a Biochrom 20 amino acid analyzer (Biochrom Ltd., Cambridge, UK), according to Directive 98/64/EC (European Commission, 1998). Plasma leptin was determined with ovine-specific radioimmunoassay (Delavaud et al., 2000) and validated for bovine plasma (Delavaud et al., 2002). The intra- and interassay CV were 6 and 9\%, respectively. Plasma insulin was assayed with commercial radioimmunoassay (Coat-ACount; Diagnostic Products Corporation, Los Angeles, $\mathrm{CA})$. The intra- and interassay CV for insulin were 8 and $6 \%$.

\section{Calculations and Statistical Methods}

Digestibility values taken from feed tables (Tuori et al., 2000) were used for calculating the feeding values of concentrates. The feeding values of silage were calculated using $\mathrm{OM}$ digestibility determined in vitro with cellulase solubility (Friedel, 1990). Energy balance was calculated as the difference between ME consumed and $\mathrm{ME}$ required for maintenance and milk production. The $\mathrm{ME}$ requirement for maintenance was calculated according to MAFF (1975), without the 5\% safety margin. Efficiency of ME use for milk production was assumed to be 0.62 . A constant value of 3.14 MJ of net energy/ $\mathrm{kg}$ of energy-corrected milk (ECM) was assumed, and ECM was calculated according to Sjaunja et al. (1991) using the formula: $\mathrm{ECM}=$ milk yield $(\mathrm{kg}) \times(38.3 \times$ milk fat $(\mathrm{g} / \mathrm{kg})+24.2 \times$ milk protein $(\mathrm{g} / \mathrm{kg})+16.54 \times$ milk lactose $(\mathrm{g} / \mathrm{kg})+20.7) / 3140$.

The postpartum data for milk yield and feed intake were reduced to weekly averages and analyzed as repeated measures, using the PROC MIXED procedure of SAS (version 6.12; SAS Institute Inc., Cary, NC). The statistical model included block, time, body fatness, glucogenic supplement, body fatness $\times$ glucogenic supplement interaction, body fatness $\times$ time interaction, glucogenic supplement $\times$ time interaction, body fatness $\times$ glucogenic supplement $\times$ time interaction, and block $\times$ time interaction. For each variable analyzed, a cow nested within the treatment was subjected to 3 covariance structures: compound symmetry (CS), unstructured (UN) and autoregressive order 1 [AR(1)]. The covariance structure that resulted in the largest Schwarz Bayesian criterion was used (Littell et al., 1996).
Milk composition, postpartum ME balance and blood composition data, lipolysis data from norepinephrine stimulation and data on DM content of the adipose tissue biopsy were analyzed as repeated measures with the PROC MIXED procedure as described above, using covariance structures CS, UN, and spatial power law [SP(POW)]. Treatment effects at specific days were determined by use of the DIFF option for the LSMEANS statement. Separate analyses using blood composition data collected during the glucogenic supplementation period were conducted to test the effect of glucogenic supplement and its interactions with body fatness and time.

Some of the lipolysis data (basal rate and effect of glucose) and blood ketone data were not normally distributed; these data were analyzed with Friedman's 2way nonparametric ANOVA using SAS. Observations from one cow (in group TG1 at d 28 of lactation) that were more than $3 \mathrm{SD}$ from the mean of the lipolysis data were considered outliers.

Body weight and BCS data and the results of the ultrasound measurements were analyzed with the PROC MIXED procedure with the model including the fixed effect of treatments and random effect of block. Relationships between BCS, FD, EB, and blood hormones and metabolites were calculated using Pearson correlation coefficients in the PROC CORR procedure of SAS.

One cow in the TG1 group suffered from teat injury; the data on this cow were not used for calculation of average milk yield and composition, or calculation of ME balance. The effects were considered to be significantly different at $P<0.05$ unless otherwise stated.

\section{RESULTS AND DISCUSSION}

\section{Changes of BCS, BW, and Fat Depth During Dry Period}

As intended, cows allocated to the $\mathrm{T}$ groups had slightly higher $(+0.16, P<0.01)$ BCS at 8 wk prepartum, and the difference remained highly significant $(P<0.01)$ until calving (Table 5). Cows in the $\mathrm{C}$ groups maintained their BCS during the dry period, whereas the increase in BCS in T group cows was smaller $(+0.14)$ than expected. Theoretically, the additional energy received by the T groups between $\mathrm{d} 56$ and 21 prepartum (38 MJ of ME/d) was sufficient for a BW gain of $1 \mathrm{~kg} /$ d. In line with this, BW gain was $1.2 \mathrm{~kg} / \mathrm{d}$ higher in the $\mathrm{T}$ groups than in the $\mathrm{C}$ groups between $\mathrm{d} 56$ and 28 prepartum, i.e., a total BW gain of $+34 \mathrm{~kg}$ (Table 5). This gain would correspond to a BCS gain of 0.8 to 1.0 according to Chilliard et al. (1991). This raises the question of whether the magnitude of the recorded BCS changes in the present study is correct. 
Table 5. Effect of body fatness and glucogenic supplement on BCS and BW between 8 wk prepartum and 8 wk postpartum.

\begin{tabular}{|c|c|c|c|c|c|c|c|c|}
\hline & \multicolumn{4}{|c|}{ Treatment $^{1}$} & \multirow[b]{3}{*}{ SEM } & \multicolumn{3}{|c|}{ Significance } \\
\hline & \multicolumn{2}{|c|}{ Control } & \multicolumn{2}{|c|}{ Test } & & \multirow{2}{*}{$\begin{array}{c}\text { Body } \\
\text { fatness }\end{array}$} & \multirow{2}{*}{$\begin{array}{l}\text { Glucogenic } \\
\text { supplement }\end{array}$} & \multirow[b]{2}{*}{ Interaction } \\
\hline & G0 & G1 & G0 & G1 & & & & \\
\hline \multicolumn{9}{|l|}{$\mathrm{BCS}$} \\
\hline Wk -8 & 2.96 & 3.00 & 3.14 & 3.14 & 0.066 & $* *$ & & \\
\hline $\mathrm{Wk}-4$ & 2.87 & 3.00 & 3.31 & 3.29 & 0.100 & $* * *$ & & \\
\hline After calving (d 0) & 2.92 & 2.93 & 3.33 & 3.23 & 0.122 & ** & NS & NS \\
\hline $\mathrm{Wk}+4$ & 2.68 & 2.71 & 2.98 & 2.86 & 0.180 & NS & NS & NS \\
\hline $\mathrm{Wk}+8$ & 2.79 & 2.73 & $2.82^{2}$ & 2.85 & $0.199^{3}$ & NS & NS & NS \\
\hline \multicolumn{9}{|l|}{$\mathrm{BW}, \mathrm{kg}$} \\
\hline $\mathrm{Wk}-8$ & 621 & 613 & 619 & 651 & 23.6 & NS & & \\
\hline $\mathrm{Wk}-4$ & 633 & 628 & 665 & 698 & 25.1 & $\dagger$ & & \\
\hline $\mathrm{Wk}-1$ & 650 & 645 & 678 & 715 & 26.7 & $\dagger$ & NS & $\mathrm{NS}$ \\
\hline After calving (d 0) & 615 & 604 & 639 & 657 & 24.5 & NS & NS & NS \\
\hline $\mathrm{Wk}+4$ & 604 & 592 & 609 & 634 & 23.1 & NS & NS & NS \\
\hline $\mathrm{Wk}+8$ & 609 & 597 & 611 & 636 & 21.6 & NS & NS & NS \\
\hline
\end{tabular}

${ }^{1}$ Control $=$ normal body fatness; Test $=$ increased body fatness; G0 = no glucogenic supplement; G1 = glucogenic supplement $(1 \mathrm{~kg} / \mathrm{d})$ between d 14 prepartum and d 56 postpartum.

${ }^{2} \mathrm{n}=5$.

${ }^{3} \mathrm{SEM}$ for Test G0 is $1.095 \times$ given SEM.

$\dagger P<0.10 ; * * P<0.01 ; * * * P<0.001$.

The subcutaneous fat layer was significantly thicker in the $\mathrm{T}$ groups at 8 and 1 wk prepartum $(P<0.01$; Table 6). However, the differences between the $\mathrm{T}$ and $\mathrm{C}$ groups were not increased during the dry period, which is at variance with the BW gain. Two possible explanations can be offered for this discrepancy. First, increases in internal fat and gut fill may have contributed disproportionately to BW gain. Second, no ultrasound measurements were performed between 8 and 1 wk before calving. Hence, the second measurement was performed $2 \mathrm{wk}$ after the removal of the additional energy allocation from the $\mathrm{T}$ groups. Cows in the $\mathrm{T}$ groups may have undergone increased lipid mobilization between $\mathrm{d} 21$ and 7 prepartum, which is suggested by a tendency toward higher plasma NEFA concentrations in these cows than in cows in the $\mathrm{C}$ groups $7 \mathrm{~d}$ prepartum. In support of this, cows in the T groups showed larger decreases in FD between $7 \mathrm{~d}$ prepartum and 1 $\mathrm{d}$ postpartum than cows in the $\mathrm{C}$ groups ( -0.9 vs. -0.3 $\mathrm{mm}, P<0.05)$.

\section{Postpartum Feed Intake and Milk Yield}

No significant effect of body fatness or glucogenic supplement was observed in postpartum feed intake or

Table 6. Effect of body fatness and glucogenic supplement on subcutaneous fat depth and diameter of the longissimus lumborum muscle between 8 wk prepartum and 4 wk postpartum.

\begin{tabular}{|c|c|c|c|c|c|c|c|c|}
\hline & \multicolumn{4}{|c|}{ Treatment $^{1}$} & \multirow[b]{3}{*}{ SEM } & \multicolumn{3}{|c|}{ Significance } \\
\hline & \multicolumn{2}{|c|}{ Control } & \multicolumn{2}{|c|}{ Test } & & \multirow{2}{*}{$\begin{array}{l}\text { Body } \\
\text { fatness }\end{array}$} & \multirow{2}{*}{$\begin{array}{l}\text { Glucogenic } \\
\text { supplement }\end{array}$} & \multirow[b]{2}{*}{ Interaction } \\
\hline & G0 & G1 & G0 & G1 & & & & \\
\hline \multicolumn{9}{|l|}{ Fat depth, mm } \\
\hline $\mathrm{Wk}-8$ & 8.7 & 8.8 & 12.9 & 13.3 & 1.45 & $* *$ & & \\
\hline $\mathrm{Wk}-1$ & 8.9 & $8.7^{2}$ & 13.2 & $13.3^{2}$ & $1.32^{3}$ & $* *$ & NS & NS \\
\hline Change wk -1 to $w \mathrm{k}+4$ & -1.1 & $-1.3^{2}$ & -1.9 & $-2.8^{2}$ & $0.47^{3}$ & $*$ & NS & NS \\
\hline \multicolumn{9}{|l|}{ Muscle diameter, mm } \\
\hline $\mathrm{Wk}-8$ & 46.8 & 43.3 & 50.0 & 49.3 & 2.86 & NS & & \\
\hline $\mathrm{Wk}-1$ & 46.0 & $41.4^{2}$ & 50.0 & $50.6^{2}$ & $2.91^{3}$ & $\dagger$ & NS & NS \\
\hline Change wk -1 to $\mathrm{d} 1$ & -1.3 & $-1.8^{2}$ & -1.8 & $-3.2^{2}$ & $0.86^{3}$ & NS & NS & NS \\
\hline Change $\mathrm{d} 1$ to $\mathrm{wk}+4$ & -4.2 & -5.8 & -9.0 & -8.3 & 1.17 & $* *$ & NS & NS \\
\hline
\end{tabular}

${ }^{1}$ Control = normal body fatness; Test $=$ increased body fatness; G0 = no glucogenic supplement; G1 = glucogenic supplement $(1 \mathrm{~kg} / \mathrm{d})$ between d 14 prepartum and d 56 postpartum.

${ }^{2} \mathrm{n}=5$.

${ }^{3} \mathrm{SEM}$ for Control G1 and Test G1 is $1.095 \times$ given SEM.

$\dagger P<0.10$; $* P<0.05$; ** $P<0.01$. 
Table 7. Effect of body fatness and glucogenic supplement on feed intake, milk yield, and milk composition of cows in wk 1 to 8 postpartum.

\begin{tabular}{|c|c|c|c|c|c|c|c|c|}
\hline & \multicolumn{4}{|c|}{ Treatment $^{1}$} & \multirow[b]{3}{*}{ SEM } & \multicolumn{3}{|c|}{ Significance } \\
\hline & \multicolumn{2}{|c|}{ Control } & \multicolumn{2}{|c|}{ Test } & & \multirow{2}{*}{$\begin{array}{c}\text { Body } \\
\text { fatness }\end{array}$} & \multirow{2}{*}{$\begin{array}{l}\text { Glucogenic } \\
\text { supplement }\end{array}$} & \multirow[b]{2}{*}{ Interaction } \\
\hline & G0 & G1 & G0 & G1 & & & & \\
\hline Silage DMI, kg/d & 8.6 & 8.7 & 8.1 & 8.3 & 0.55 & NS & NS & NS \\
\hline Total DMI, kg/d & 20.9 & 20.8 & 19.6 & 20.5 & 0.59 & NS & NS & NS \\
\hline Milk, kg/d & 38.2 & 41.0 & 39.6 & $41.4^{2}$ & $1.32^{3}$ & NS & NS & NS \\
\hline Fat, g/kg & 42.0 & 42.9 & 42.7 & $42.2^{2}$ & $1.11^{3}$ & NS & NS & NS \\
\hline Protein, $\mathrm{g} / \mathrm{kg}$ & 33.8 & 32.9 & 32.2 & $32.6^{2}$ & $0.39^{3}$ & $*$ & NS & NS \\
\hline Lactose, $\mathrm{g} / \mathrm{kg}$ & 46.6 & 47.5 & 46.8 & $45.9^{2}$ & $0.68^{3}$ & NS & NS & NS \\
\hline Urea, $\mathrm{mg} / \mathrm{dL}$ & 31.6 & 29.8 & 27.9 & $26.4^{2}$ & $1.51^{3}$ & * & NS & NS \\
\hline $\mathrm{ECM},{ }^{4} \mathrm{~kg} / \mathrm{d}$ & 38.8 & 42.0 & 39.5 & $41.4^{2}$ & $1.67^{3}$ & NS & NS & NS \\
\hline
\end{tabular}

\footnotetext{
${ }^{1}$ Control = normal body fatness; Test $=$ increased body fatness; G0 = no glucogenic supplement; G1 = glucogenic supplement $(1 \mathrm{~kg} / \mathrm{d})$ between d 14 prepartum and d 56 postpartum.

${ }^{2}$ Observations from one cow omitted due to teat injury.

${ }^{3} \mathrm{SEM}$ for Test G1 is $1.125 \times$ given SEM.

${ }^{4} \mathrm{ECM}=$ Energy-corrected milk.

$* P<0.05$.
}

milk yield (Table 7). Milk protein and urea contents were lower $(P<0.05)$ in the $\mathrm{T}$ groups than in the $\mathrm{C}$ groups. There was a significant time $\times$ body fatness interaction on ECM $(P<0.001)$. Cows in the T groups tended to increase ECM faster than cows in the C groups during the first $4 \mathrm{wk}$ of lactation.

\section{Lipid Mobilization}

No significant differences were found between treatments in changes in BCS and BW after calving. Nevertheless, a significant difference in BCS, which was observed between $\mathrm{C}$ and $\mathrm{T}$ groups before calving, disappeared after calving (Table 5). In parallel, steeper decreases in FD were seen in T groups between $1 \mathrm{wk}$ prepartum and 4 wk postpartum (Table 6), and estimated $\mathrm{EB}$ was more negative in $\mathrm{T}$ groups than in $\mathrm{C}$ groups at wk 1 and 2 of lactation (Figure 1).

The average correlation coefficients between BCS and FD measured at 3 different sites ranged between 0.61 and $0.67(P<0.01)$ at site 1 , between 0.43 and $0.52(P$ $<0.05)$ at site 2 , and between 0.62 and $0.65(P<0.01)$ at site 3 . The significant positive correlations between BCS and FD are in agreement with previous findings (Garnsworthy and Topps, 1982; Domecq et al., 1995). The significant positive correlation between muscle diameter and BCS (range 0.62 to $0.65, P<0.01$ ) suggests, as does Reid et al. (1986), that BCS not only covers assessment of fat reserves, but also assessment of protein reserves in skeletal muscles which are located under the skin areas where body condition is scored.

In agreement with earlier studies (Kunz et al., 1985; Vazquez-Anon et al., 1994), plasma NEFA was moderately increased during the week preceding calving, peaked at $\pm 1 \mathrm{~d}$ from calving, and began to decrease within 1 wk after calving. Figure 2 a shows that the T groups tended to have higher plasma NEFA as calving approached and during the early weeks of lactation. This suggests that, compared with leaner cows in the $\mathrm{C}$ groups, the cows in the T groups initiated more extensive mobilization of body fat before calving which continued during the first weeks of lactation. This is in agreement with earlier studies showing higher postpartum BCS or BW losses (Garnsworthy and Topps, 1982; Treacher et al., 1986) or blood NEFA concentrations (Reid et al., 1986; Rukkwamsuk et al., 1998) in overconditioned cows or cows with high-energy prepartum feeding. It must be noted that grass silage was given ad libitum in the present trial and a high daily concentrate allowance $(15 \mathrm{~kg} / \mathrm{d}$ ) was achieved rapidly (16 d) after calving. The effect of body fatness at calving on negative energy balance, BW and BCS losses, plasma NEFA increase, and adipose cell size decrease is much more marked when cows are restrictively fed after calving, than in cows fed ad libitum (Chilliard, 1992).

Glucogenic supplement contained propylene glycol, xylitol, and niacin, which are potentially antilipolytic and antiketogenic substrates (Sakai et al., 1996; Nielsen and Ingvartsen, 2000, 2004). In the current study, glucogenic supplement did not change the concentrations of plasma NEFA and insulin. In fact, the cows with glucogenic supplement had higher plasma NEFA concentration $(P=0.05)$ in parallel with a trend for increased milk yield $(P=0.11)$.

\section{Blood BHBA and Glucose}

The decreased availability of glucose precursors in the liver during early lactation increases ketone body 


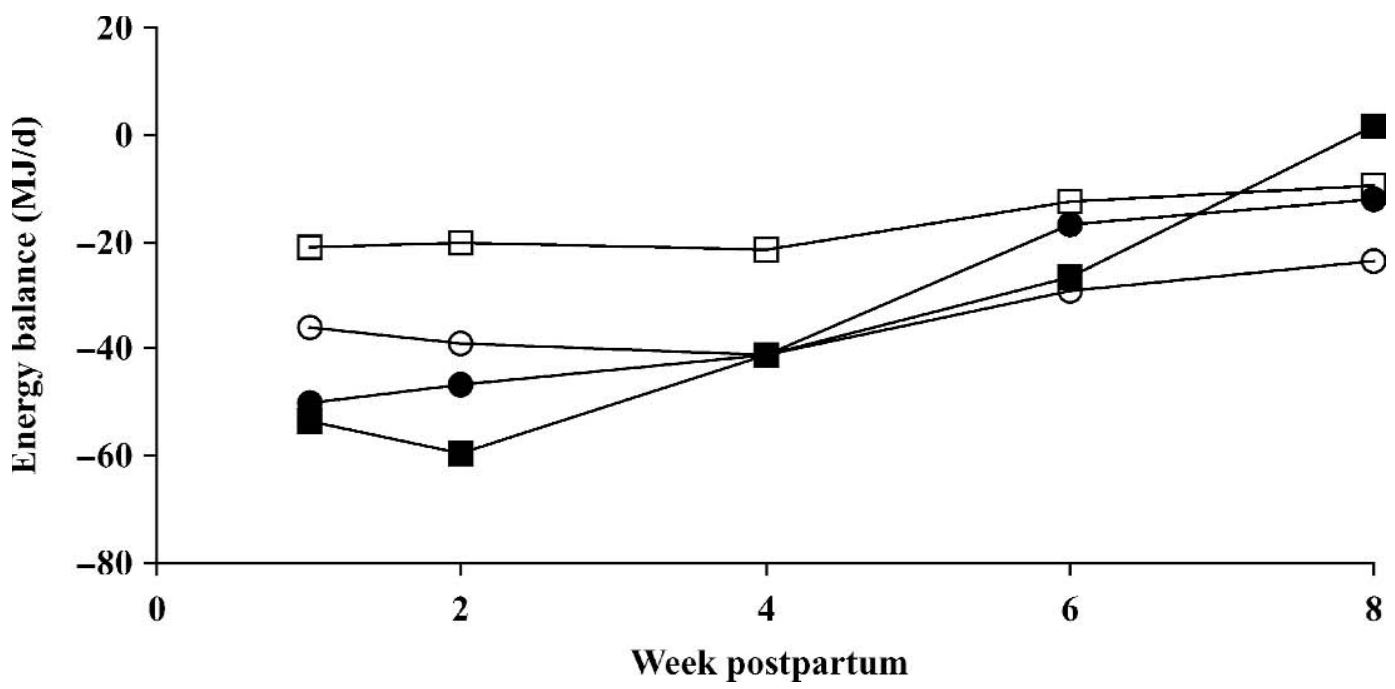

Figure 1. Effect of body fatness and glucogenic feed on postpartum energy balance. Pooled SEM = 8.05 in groups CG0, CG1, and TG0, and 9.06 in group TG1. Interaction body fatness $\times$ time $(P<0.001)$. Treatments control (open symbols) and test (solid symbols) correspond to cows with normal and increased body fatness. Treatments G0 (squares) and G1 (circles) correspond to 0 and $1 \mathrm{~kg} / \mathrm{d}$ glucogenic feed between d 14 prepartum and d 56 postpartum, respectively.

production because of the high rate of gluconeogenesis and limited entry of exogenous nutrients (Chilliard, 1999). Our previous experiment (Kokkonen et al., 2000) showed the antiketogenic potential of glucogenic supplement containing propylene glycol, polyols, and niacin. The current results partly confirm this (Figure $2 b$ ). This suggests that cows with larger mobilizable fat depots may benefit from intake of glucogenic supplement. Similarly, a recent review by Nielsen and Ingvartsen (2004) shows that propylene glycol induces the largest decreases in plasma BHBA in animals with higher NEFA concentrations.

Increased BHBA during early lactation of fatter cows in the TG0 group (Figure 2b) is in agreement with the findings of Kunz et al. (1985). Rukkwamsuk et al. (1998) also observed a similar tendency, whereas Reid et al. (1986) and Tesfa et al. (1999) detected no effects of body fatness or dry period overfeeding on blood BHBA. The variation between studies was probably due to differences in milk production levels, feeding regimens, and the degree of energy balance and fatty acid mobilization.

The general pattern of plasma glucose concentrations was similar to that seen in previous studies (Kunz et al., 1985; Vazquez-Anon et al., 1994), showing a rapid decrease after calving. The mean glucose concentrations $(\mathrm{mg} / \mathrm{dL})$ at $\mathrm{d}-21,-7,-1,1,7,28$, and 56 relative to calving were $68.7,65.7,68.8,67.1,47.3,48.8$, and 54.7 (pooled SEM = 1.22). The extent of the decrease could be even more dramatic in our study than in earlier studies, due to blood sampling from the mammary vein, and hence increased mammary uptake of glucose dur- ing lactation. In accordance with earlier findings (Kunz et al., 1985; Reid et al., 1986; Rukkwamsuk et al., 1998), body fatness had no consistent effect on postpartum glucose concentrations.

Plasma glucose concentrations were not increased with glucogenic supplementation. The increased glucose requirement for lactose synthesis may have accounted for the absence of differences in plasma glucose in the mammary vein between G0 and G1 groups after calving, because the glucogenic supplement tended to increase the milk yield $(P=0.11)$.

\section{In Vitro Lipolysis}

Large differences were observed in lipolytic activity among individual biopsy specimens. Although this made it difficult to detect potential differences between treatments, some clear trends were observed. First, the mean DM content of biopsy specimens decreased from $802 \mathrm{~g} / \mathrm{kg}$ at calving to $740 \mathrm{~g} / \mathrm{kg}$ at d 7 postpartum, indicating increased tissue hydration together with increased lipid mobilization; the differences between treatments or treatment $\times$ time interaction were not statistically significant. In agreement with our results, earlier studies with lactating goats showed a strong negative correlation of lipid and water contents of adipose tissue (Bas et al., 1987). Second, in contrast to earlier studies (Metz and van den Bergh, 1977; McNamara and Hillers, 1986), the basal rate of glycerol release from adipose tissue samples was decreased at the time of calving (Figure 3a) and did not reach the prepartum level by $28 \mathrm{~d}$ postpartum. This discrepancy 
A.

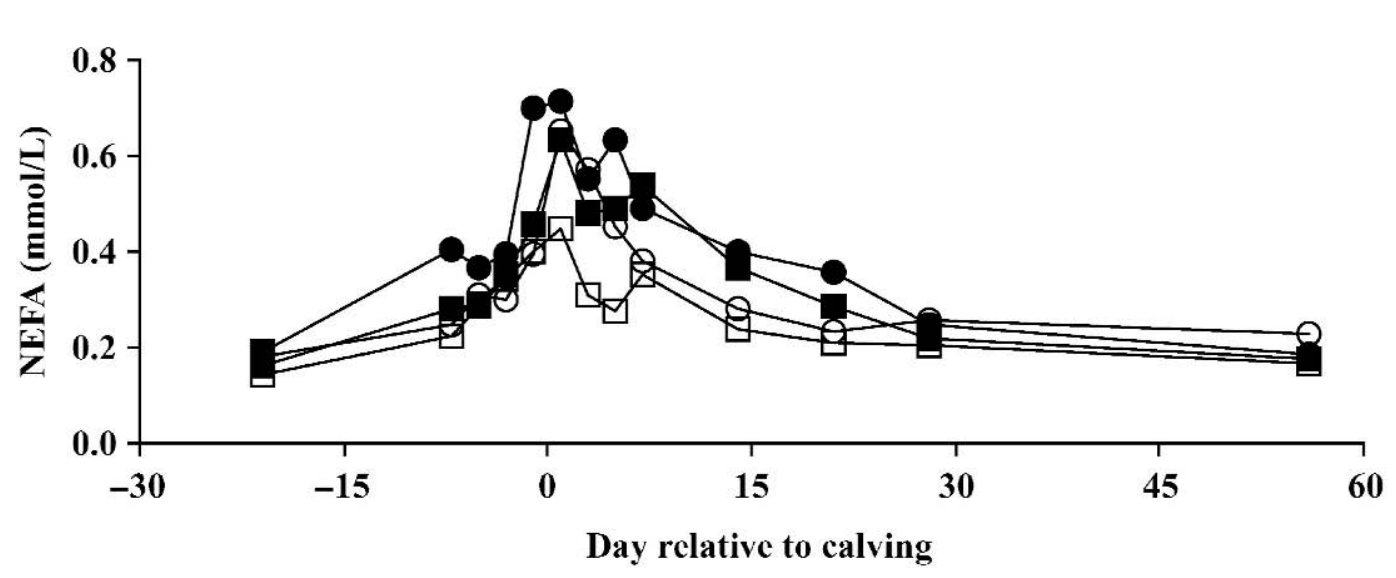

B.

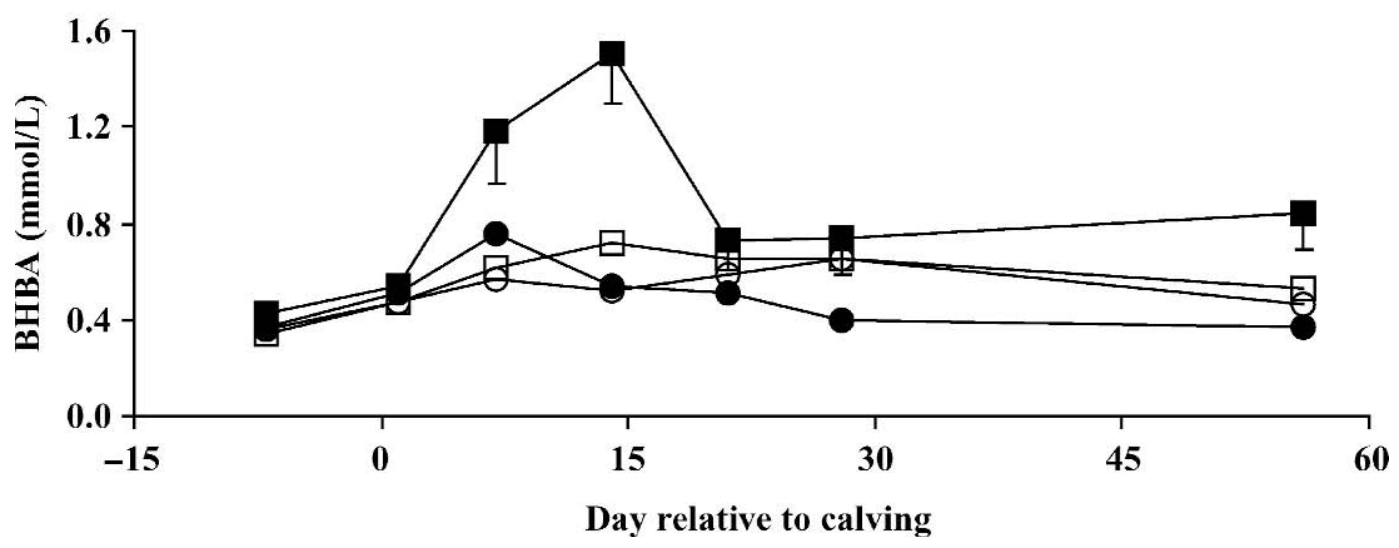

Figure 2. Effect of body fatness and glucogenic feed on (a) plasma NEFA and (b) blood BHBA concentrations around the time of calving. Pooled SEM $=0.03$ for NEFA. Error bars indicate SEM for BHBA. Effect of body fatness on NEFA $(P=0.01)$, effect of glucogenic supplement on NEFA $(P=0.05)$, and interaction body fatness $\times$ time $(P=0.10)$ on NEFA. Effect of body fatness on BHBA at d 14 of lactation $(P=0.02)$, effect of glucogenic supplement on BHBA at d 14 and 21 of lactation $(P=0.01$ and $P=0.02)$, and interaction body fatness $\times$ glucogenic supplement at d 7, 14, and 56 of lactation $(P=0.05, P=0.03$, and $P=0.02)$. Treatments control (open symbols) and test (solid symbols) correspond to cows with normal and increased body fatness. Treatments G0 (squares) and G1 (circles) correspond to 0 and $1 \mathrm{~kg} / \mathrm{d}$ glucogenic supplement between d 14 prepartum and d 56 postpartum, respectively.

could be because our cows were fed with a restricted amount of feed during the final weeks of pregnancy. Similarly, Rukkwamsuk et al. (1998) observed a greater decline in basal lipolytic rate with restrictively fed cows than with overfed cows during the periparturient period. Because in vitro glycerol release reflects lipolysis quite well (Chilliard, 1999), this raises the question of whether restricted feeding during the final weeks of pregnancy increases the risk of hepatic lipid accumulation. In the present trial, the plasma NEFA concentration was slightly increased between $d 21$ (beginning of restricted feeding) and 7 prepartum (Figure 2a). During the final week of pregnancy, plasma NEFA continued to increase; however, the corresponding NEFA profile was also observed with ad libitum feeding (Grummer, 1993). Furthermore, a study by Vazquez-Anon et al. (1994) showed that in the absence of a prolonged DMI depression, liver triglycerides infiltration did not occur until the acute rise in NEFA at calving.

The low rate of basal glycerol release postpartum, compared with the simultaneous increase in plasma NEFA, could reflect a sharp decrease in FA re-esterification in adipose tissue (Metz and van den Bergh, 1977). It was shown by Gagliostro and Chilliard (1991) that the in vitro NEFA:glycerol ratio was much higher in early than in midlactation cows. No lowering effect of 


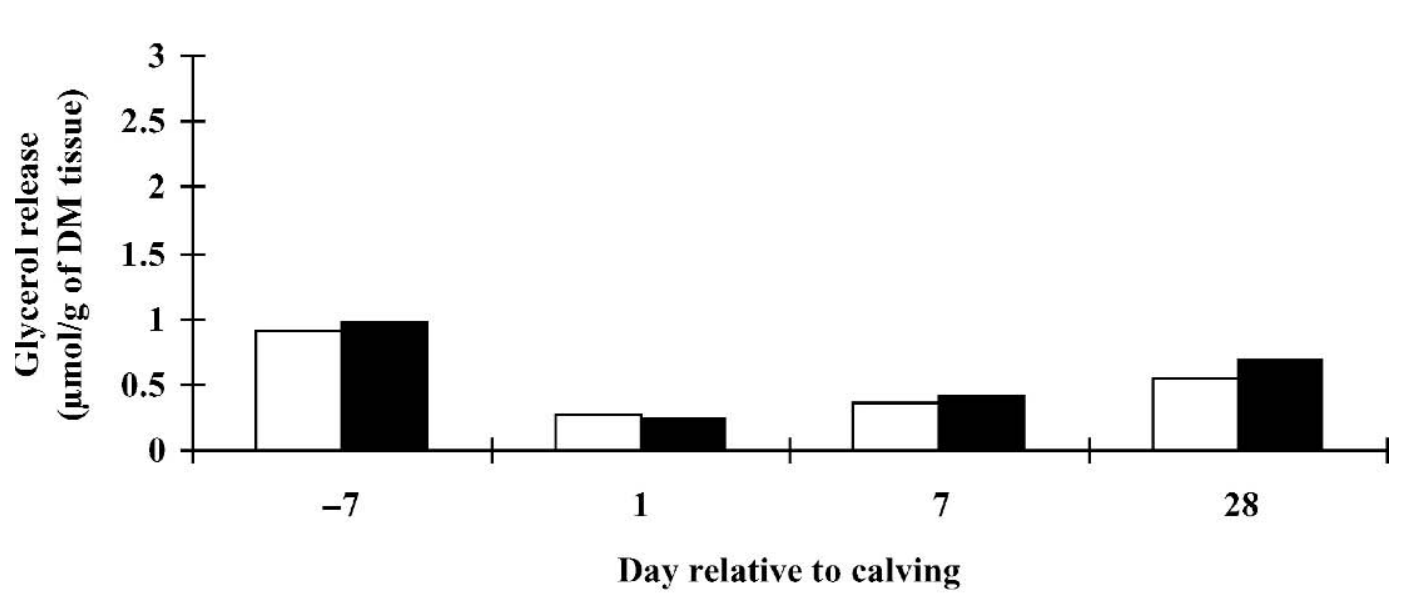

B

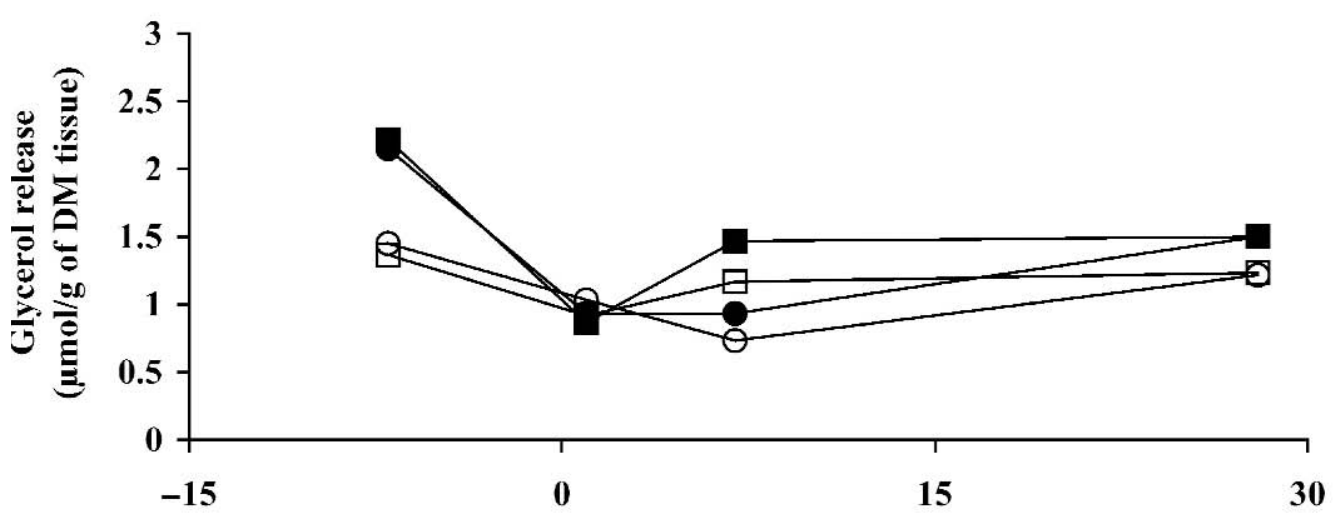

Day relative to calving

Figure 3. Glycerol release from subcutaneous adipose tissue around the time of calving. A: Changes of lipolytic rates in basal conditions (open bars, pooled SEM = 0.11) or with added glucose (shaded bars, pooled SEM = 0.12). Data from treatment groups were pooled because no significant differences between treatments were observed and body fatness $\times$ glucogenic supplement interaction was not significant. B: Effect of body fatness and glucogenic supplement on norepinephrine-stimulated lipolytic rate (pooled SEM $=0.16$ ). Effect of body fatness $(P=0.08)$ and interaction body fatness $\times$ time $(P=0.07)$. Treatments control (open symbols) and test (solid symbols) correspond to cows with normal and increased body fatness. Treatments G0 (squares) and G1 (circles) correspond to 0 and $1 \mathrm{~kg} / \mathrm{d}$ glucogenic supplement between d 14 prepartum and d 56 postpartum, respectively.

glucose on glycerol release was detected (Figure 3a), which is consistent with the results of Metz and van den Bergh (1977).

The decrease of norepinephrine-stimulated glycerol release at calving (Figure 3b) was not as pronounced as the decrease of basal rate (Figure 3a). In agreement with Rukkwamsuk et al. (1998), norepinephrine-stimulated glycerol release relative to basal rate increased after calving. One week before calving, the norepinephrine-stimulated glycerol release was higher $(P<0.05)$ in samples taken from cows in the $\mathrm{T}$ groups, which received high-energy feeding during the early dry period. The trend $(P<0.10)$ toward higher response to norepinephrine stimulation could also be seen $1 \mathrm{wk}$ after calving. These results suggest that increased fatness amplifies the lipolytic response of adipose tissue to norepinephrine stimulation, even if the cows are not overfed during the immediate prepartum period.

\section{Protein Mobilization}

The longissimus lumborum muscle tended $(P=0.05)$ to be thicker in $\mathrm{T}$ groups $1 \mathrm{wk}$ before calving (Table 6 ), 


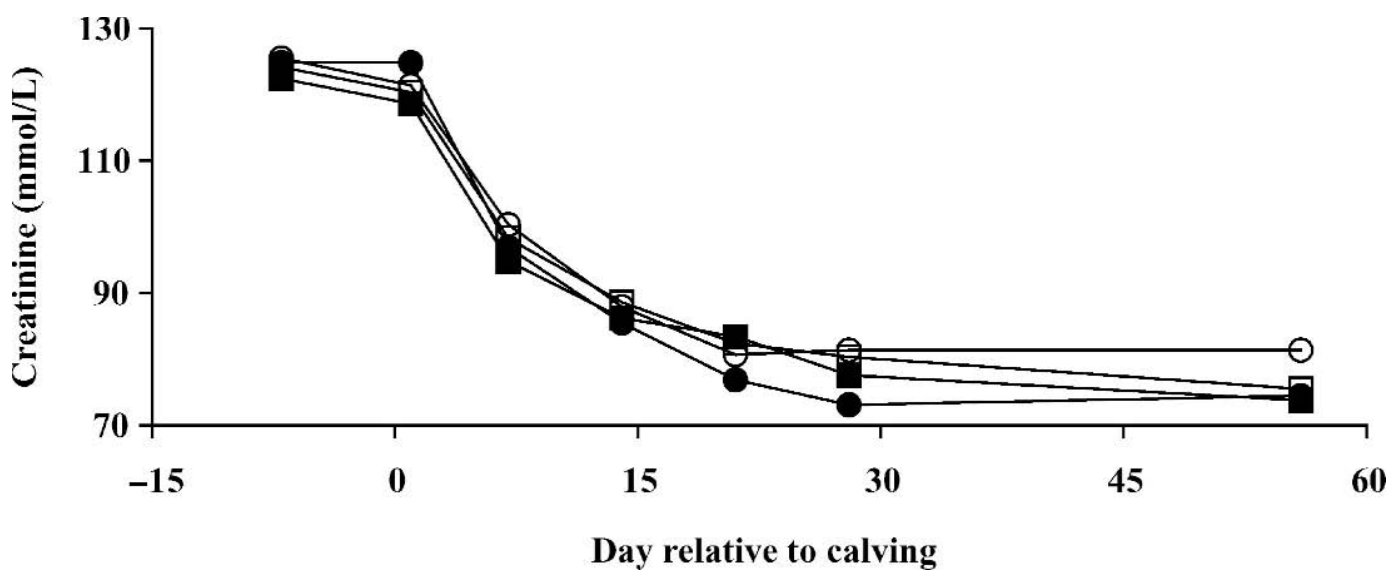

Figure 4. Effect of body fatness and glucogenic supplement on plasma creatinine concentration around the time of calving. Pooled SEM = 3.5. Interaction glucogenic supplement $\times$ time $(P=0.005)$. Treatments control (open symbols) and test (solid symbols) correspond to cows with normal and increased body fatness. Treatments G0 (squares) and G1 (circles) correspond to 0 and $1 \mathrm{~kg} / \mathrm{d}$ glucogenic supplement between d 14 prepartum and d 56 postpartum, respectively.

and at the beginning of the experiment $(P=0.13)$. Thus, allocating the cows to energy levels according to BCS not only yielded groups with unequal lipid stores but probably also with unequal protein stores in the muscles.

The decrease of muscle diameter started between $7 \mathrm{~d}$ prepartum and $1 \mathrm{~d}$ postpartum in all groups, suggesting that protein mobilization was initiated before calving. After calving, the decrease of muscle diameter continued until to the last measurement at d 28 of lactation. A parallel decrease of plasma creatinine from 121 to $81 \mathrm{mmol} / \mathrm{L}$ between $\mathrm{d} 1$ and 21 of lactation was observed in all groups (Figure 4), indicating a decrease in total muscle mass.

The decrease in muscle diameter was more pronounced $(P<0.01)$ in the $\mathrm{T}$ groups than in the $\mathrm{C}$ groups (Table 6) between 1 and $28 \mathrm{~d}$ postpartum. In line with this, Reid et al. (1986) reported that the muscle (m. trapezius thoracalis) fiber area of fat cows decreased significantly around calving, whereas that of thin cows did not decrease. Thus, cows in the T groups demonstrated more protein mobilization in parallel with more lipid mobilization.

The plasma 3-MH measurements were too few to adequately describe protein mobilization postpartum. The mean $3-\mathrm{MH}$ concentrations $(\mu \mathrm{mol} / \mathrm{L})$ at $\mathrm{d}-7,1$, and 28 relative to calving were $8.8,13.0$, and 5.8 (pooled SEM = 1.28), with no differences between treatments. Nevertheless, at d 28 of lactation, the mean 3-MH concentrations were below the concentrations detected 7 $\mathrm{d}$ prepartum, indicating that the most extensive period of protein mobilization was over by that time. This was further supported in the study by Burhans et al. (1997), who found that plasma 3-MH declined to basal levels by $21 \mathrm{~d}$ postpartum.
Glucogenic supplement did not decrease amino acid mobilization, as indicated by ultrasound measurements (Table 6) and 3-MH. On the other hand, the decrease of plasma creatinine continued between $\mathrm{d} 28$ and 56 of lactation in G0 groups, whereas plasma creatinine in G1 cows leveled off (Figure 4). This may indicate that protein mobilization was prolonged in G0 groups.

\section{Plasma Leptin}

A considerable decrease in plasma leptin during the final days of pregnancy and the first days of lactation (Figure 5a) is in agreement with recent reports (Block et al., 2001; Holtenius et al., 2003; Liefers et al., 2003; Reist et al., 2003) based on ruminant-specific leptin assays. The study by Block et al. (2001) showed that the decrease in leptin is associated with the onset of copious milk production followed by negative EB, because the leptin decrease was not observed in cows that were not milked after parturition. Although the cows in the $\mathrm{T}$ groups showed a more negative EB (Figure 1) and more intensive lipid mobilization during early weeks of lactation, they still had higher $(P<0.05)$ concentrations of plasma leptin than cows in the $\mathrm{C}$ groups. Nevertheless, the differences between groups were smaller postpartum than prepartum.

In general, the presence of higher concentrations of plasma leptin with increased adiposity is in agreement with reports showing that adipose tissue is the largest contributor of plasma leptin in ruminants (Chilliard et al., 2001). In agreement with Reist et al. (2003), significant positive correlations (Table 8 ) were observed between body condition and plasma leptin as well as subcutaneous FD measured with ultrasound and plasma leptin at all days measured, with the slight 
A.

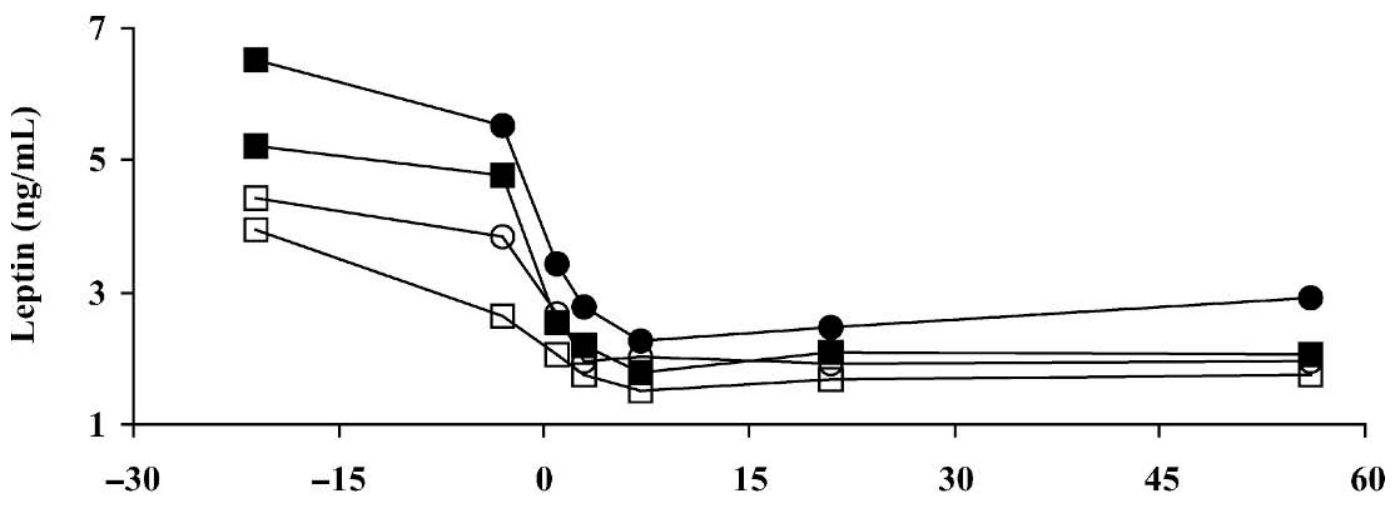

Day relative to calving

B.

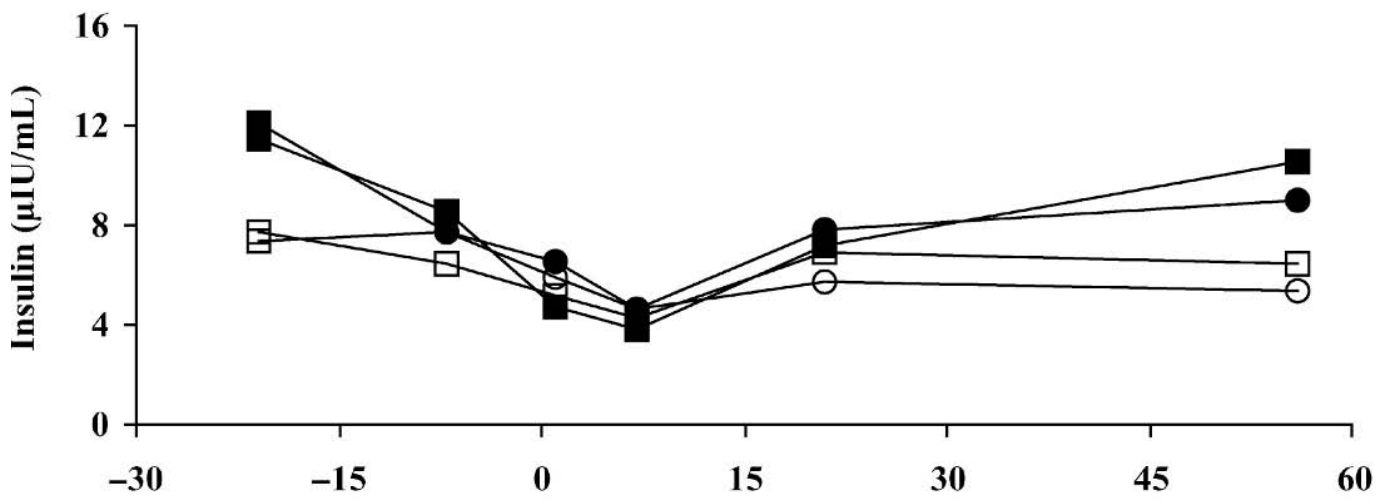

Day relative to calving

Figure 5. Effect of body fatness and glucogenic feed on plasma (a) leptin and (b) insulin concentrations around the time of calving. Pooled $\mathrm{SEM}=0.36$ and 0.94 for leptin and insulin, respectively. Effect of body fatness on leptin $(P=0.03)$ and on insulin $(P=0.09)$. Effect of glucogenic supplement on leptin $(P=0.08)$. Interaction body fatness $\times$ time $(P=0.03)$ on insulin. Treatments control (open symbols) and test (solid symbols) correspond to cows with normal and increased body fatness. Treatments G0 (squares) and G1 (circles) correspond to 0 and $1 \mathrm{~kg} / \mathrm{d}$ glucogenic supplement between d 14 prepartum and d 56 postpartum, respectively.

exception of $\mathrm{d} 7$ after calving. Significant positive correlation between leptin and insulin (and glucose at $\mathrm{d}-21$ and +21$)$ is in agreement with a study by Block et al. (2001), whereas the lack of correlation between leptin and NEFA is not. Blood collection from the mammary vein may account for the absence of correlation. Mammary uptake decreases the concentrations of metabolites during lactation and probably decreases the variability of the concentrations more markedly in mammary than in jugular venous blood.

Plasma leptin tended to be higher with glucogenic supplementation $(P=0.08)$, without significant differ- ences in EB and with a coincidental trend toward higher milk yield $(P=0.11)$. This result is in agreement with the study of Francisco et al. (2002), showing higher concentrations of plasma leptin in Propionibacteriatreated cows, which tended to have lower EB. On the other hand, Reist et al. (2003) observed that plasma leptin and EB were higher in early lactating cows receiving 50 rather than $30 \%$ concentrate in total dietary DM. In the present study, in which no significant differences in adiposity, feed intake, plasma glucose, or insulin (Figure 5b) were observed between groups G0 and G1, no obvious rationalization for the tendency toward 
Table 8. Correlations between plasma leptin and BCS, fat depth, energy balance, and some blood hormones and metabolites between $21 \mathrm{~d}$ prepartum and $56 \mathrm{~d}$ postpartum.

\begin{tabular}{lcccccc}
\hline & $-21 \mathrm{~d}^{1}$ & $-3 \mathrm{~d}^{2}$ & $+1 \mathrm{~d}$ & $+7 \mathrm{~d}$ & $+21 \mathrm{~d}^{3}$ & $+56 \mathrm{~d}$ \\
\hline $\mathrm{n}$ & 24 & 22 & 23 & 24 & 24 & 24 \\
BCS & $0.48^{*}$ & $0.72^{* * *}$ & $0.55^{* *}$ & 0.32 & $0.65^{* * *}$ & $0.56^{* * 4}$ \\
Fat depth & & $0.90^{* * *}$ & $0.74^{* * *}$ & $0.42^{* *}$ & $0.73^{* * *}$ & \\
Insulin & $0.73^{* * *}$ & $0.51^{*}$ & $0.49^{*}$ & $0.46^{*}$ & $0.53^{* *}$ & $0.46^{*}$ \\
Glucose & $0.53^{* *}$ & 0.21 & $0.25^{5}$ & $0.37 \dagger$ & $0.48^{*}$ & $0.36 \dagger$ \\
NEFA & -0.24 & 0.11 & -0.07 & 0.07 & 0.10 & -0.06 \\
BHBA & & -0.11 & -0.15 & 0.16 & -0.19 & -0.19 \\
Energy balance & & & & -0.25 & -0.08 & 0.12 \\
\hline
\end{tabular}

${ }^{1} \mathrm{BCS}$ data from $-28 \mathrm{~d}$.

${ }^{2} \mathrm{BCS}$, fat depth, insulin, and BHBA data from $-7 \mathrm{~d}$.

${ }^{3} \mathrm{BCS}$, fat depth, and energy balance data from $+28 \mathrm{~d}$.

${ }^{4} \mathrm{n}=23$.

${ }^{5} \mathrm{n}=22$.

$\dagger P<0.10 ; * P<0.05 ; * * P<0.01 ; * * P<0.001$.

increased leptin concentration can be given, and we could speculate on an effect of specific nutrients which were present in the supplement or were increased at the gut level during digestion processes.

\section{CONCLUSIONS}

The current experiment provides evidence that the more extensive lipid mobilization occurring in cows with larger mobilizable fat depots begins during the final week of pregnancy and might be due to increased responsiveness to adrenergic stimulation. With restricted feeding during the immediate prepartum period, the onset of lactation brought along a decrease rather than an increase of in vitro basal lipolytic rate. The glucogenic supplement did not decrease lipid mobilization; however, it prevented excessive formation of ketone bodies in cows with extensive lipid mobilization. Protein mobilization was augmented during the final week of pregnancy and tended to increase more in fatter cows.

Fatter cows showed a higher concentration of plasma leptin prepartum and a more pronounced decrease in leptin concentration during the final week of pregnancy and the first week of lactation. Despite a more negative EB, fatter cows still had higher concentration of plasma leptin after calving. Moreover, the glucogenic supplement tended to increase plasma leptin despite the simultaneous tendencies toward increased milk yield and tissue mobilization. These results suggest that plasma leptin concentration in early-lactation cows is primarily and closely associated with body fatness, and could be affected to some extent by specific nutrients.

\section{ACKNOWLEDGMENTS}

The authors wish to thank Juha Suomi and the staff of Viikki Research Farm for caring for the experimental animals. Tuomo Kokkonen received financial support from the Finnish Cultural Foundation. The authors thank Suomen Rehu Oy for providing financial support for this experiment.

\section{REFERENCES}

Bas, P., Y. Chilliard, P. Morand-Fehr, A. Rouzeau, and N. Mandran. 1987. Composition des principaux tissus adipeux de la chèvre Alpine en fin de lactation. Ann. Zootech. 36:361-374.

Bell, A. W., W. S. Burhans, and T. R. Overton. 2000. Protein nutrition in late pregnancy, maternal protein reserves and lactation performance in dairy cows. Proc. Nutr. Soc. 59:119-126.

Block, S. S., W. R. Butler, R. A. Ehrhardt, A. W. Bell, M. E. Van Amburgh, and Y. R. Boisclair. 2001. Decreased concentration of plasma leptin in periparturient dairy cows is caused by negative energy balance. J. Endocrinol. 171:339-348.

Burhans, W. S., and A. W. Bell. 1998. Feeding the transition cow. Pages 247-258 in Proc. Cornell Nutr. Conf. Feed Manuf., Syracuse, NY. Cornell Univ., Ithaca, NY.

Burhans, W. S., E. A. Briggs, J. A. Rathmacher, and A. W. Bell. 1997. Glucogenic supplementation does not reduce body tissue protein degradation in periparturient dairy cows. J. Dairy Sci. 80(Suppl. 1):166. (Abstr.)

Chilliard, Y. 1992. Physiological constraints to milk production: Factors which determine nutrient partitioning, lactation persistency, and mobilization of body reserves. World Rev. Anim. Prod. 27:19-26.

Chilliard, Y. 1999. Metabolic adaptations and nutrient partitioning in the lactating animal. Pages 503-552 in Biology of Lactation. J. Martinet, L-M. Houdebine, and H. H. Head, ed. INRA, Paris, France.

Chilliard, Y., M. Bonnet, C. Delavaud, Y. Faulconnier, C. Leroux, J. Djiane, and F. Bocquier. 2001. Leptin in ruminants. Gene expression in adipose tissue and mammary gland, and regulation of plasma concentration. Domest. Anim. Endocrinol. 21:271-295.

Chilliard, Y., M. Cissé, R. Lefaivre, and B. Rémond. 1991. Body composition of dairy cows according to lactation stage, somatotropin treatment and concentrate supplementation. J. Dairy Sci. 74:3103-3116.

Chilliard, Y., and J. Robelin. 1983. Mobilization of body proteins by early lactating cows measured by slaughter and D2O techniques. Pages 195-198 in IVth Int. Symp. Protein metabolism and nutrition. EAAP Publication no. 31, vol. 2. EAAP, Rome Italy.

Delavaud, C., F. Bocquier, Y. Chilliard, D. H. Keisler, A. Gertler, and G. Kann. 2000. Plasma leptin determination in ruminants: Effect of nutritional status and body fatness on plasma leptin concentra- 
tion assessed by a specific RIA in sheep. J. Endocrinol. 165:519-526.

Delavaud, C., A. Ferlay, Y. Faulconnier, F. Bocquier, G. Kann, and Y. Chilliard. 2002. Plasma leptin concentration in adult cattle: Effects of breed, adiposity, feeding level, and meal intake. J. Anim. Sci. 80:1317-1328.

Domecq, J. J., A. L. Skidmore, J. W. Lloyd, and J. B. Kaneene. 1995. Validation of body condition scores with ultrasound measurements of subcutaneous fat of dairy cows. J. Dairy Sci. 78:23082313.

Edmonson, A. J., I. J. Lean, L. D. Weaver, T. Farver, and G. Webster. 1989. A body condition chart of Holstein dairy cows. J. Dairy Sci. 72:68-78.

European Commission. 1998. Commission Directive 98/64/EC. Community methods of analysis for the determination of amino acids, crude oils and fats, and olaquindox in feeding stuffs and amending Directive 71/393/EEC. European Commission, Brussels, Belgium.

Fabiny, D. L., and G. Ertigshausen. 1971. Automated reaction rate method for determination of serum creatinine with CentrifiChem. Clin. Chem. 17:696-700.

Francisco, C. C., C. S. Chamberlain, D. N. Waldner, R. P. Wettemann, and L. J. Spicer. 2002. Propionibacteria fed to dairy cows: Effects on energy balance, plasma metabolites and hormones, and reproduction. J. Dairy Sci. 85:1738-1751.

Friedel, K. 1990. Die schätzung des energetischen futterwertes von grobfutter mit hilfe einer cellulasemethode. Wissenschaft. Z. Uni. Rostock, N-Reihe 39:78-86.

Gagliostro, G., and Y. Chilliard. 1991. Duodenal rapeseed oil infusion in early and midlactation cows. 4 . In vivo and in vitro adipose tissue lipolytic responses. J. Dairy Sci. 74:1830-1843.

Garnsworthy, P. C., and J. H. Topps. 1982. The effect of body condition of dairy cows at calving on their food intake and performance when given complete diets. Anim. Prod. 35:113-119.

Grummer, R. R. 1993. Etiology of lipid-related metabolic disorders in periparturient dairy cows. J. Dairy Sci. 76:3882-3896.

Hansen, J. L., and E. F. Freier. 1978. Direct assays of lactate, pyruvate, $\beta$-hydroxybutyrate and acetoacetate with a centrifugal analyzer. Clin. Chem. 24:475-479.

Holtenius, K., S. Agenäs, C. Delavaud, and Y. Chilliard. 2003. Effects of feeding intensity during the dry period. 2. Metabolic and hormonal responses. J. Dairy Sci. 86:883-891.

Ingvartsen, K. L., and Y. R. Boisclair. 2001. Leptin and the regulation of food intake, energy homeostasis and immunity with special focus on periparturient ruminants. Domest. Anim. Endocrinol. $21: 215-250$

Kokkonen, T., A. Tesfa, M. Tuori, K. Hissa, E. Jukola, and L. SyrjäläQvist. 2000. Effects of early lactation concentrate level and glucogenic feed on feed intake, milk production and energy metabolism in dairy cows and heifers. J. Anim. Feed Sci. 9:563-583.

Kokkonen, T., A. T. Tesfa, M. Tuori, S. Yrjänen, and L. Syrjälä-Qvist. 2002. Effects of concentrate crude protein level on grass silage intake, milk yield and nutrient utilisation by dairy cows in early lactation. Arch. Anim. Nutr. 56:213-227.

Kunz, P. L., J. W. Blum, I. C. Hart, H. Bickel, and J. Landis. 1985. Effect of different energy intakes before and after calving on food intake, performance and blood hormones and metabolites in dairy cows. Anim. Prod. 40:219-231.

Liefers, S. C., R. F. Veerkamp, M. F. W. te Pas, C. Delavaud, Y. Chilliard, and T. Van der Lende. 2003. Leptin levels in relation to energy balance, milk yield, dry matter intake, live weight, and fertility in dairy cows. J. Dairy Sci. 86:798-807.
Littell, R. C., G. A. Milliken, W. W. Stroup, and R. D. Wolfinger. 1996. SAS system for mixed models. SAS Inst., Inc., Cary, NC.

MAFF (Ministry for Agriculture, Fisheries and Food). 1975. Energy allowance and feeding system for ruminants. Tech. Bull. 33, Her Majesty's Stationery Office, London, UK.

McGowan, M. W., J. D. Artiss, D. R. Strandbergh, and B. Zak. 1983. A peroxidase-coupled method for the colorimetric determination of serum triglycerides. Clin. Chem. 29:538-542.

McNamara, J. P., and J. K. Hillers. 1986. Adaptations in lipid metabolism of bovine adipose tissue in lactogenesis and lactation. J. Lipid Res. 27:150-157.

Metz, S. M. H., and S. G. van den Bergh. 1977. Regulation of fat mobilization in adipose tissue of dairy cows in the period around parturition. Neth. J. Agric. Res. 25:198-211.

Nielsen, N., and K. L. Ingvartsen. 2000. Niacin for dairy cows: Biological effect and effect on feed intake, fermentation pattern in rumen, blood parameters, performance and risk of fatty liver and ketosis (In Danish). Danmarks Jordbrugsforskning rapport, Husdyrbrug nr. 20.

Nielsen, N., and K. L. Ingvartsen. 2004. Propylene glycol for dairy cows: A review of the metabolism of propylene glycol and its effects on physiological parameters, feed intake, milk production and risk of ketosis. Anim. Feed Sci. Technol. 115:191-213.

Reid, I. M., C. J. Roberts, R. J. Treacher, and L. A. Williams. 1986. Effect of body condition at calving on tissue mobilization, development of fatty liver and blood chemistry of dairy cows. Anim. Prod. 43:7-15.

Reist, M., D. Erdin, D. von Euw, K. Tschümperlin, H. Leuenberger, C. Delavaud, Y. Chilliard, H. M. Hammon, N. Kuenzi, and J. W. Blum. 2003. Concentrate feeding strategy in lactating dairy cows: Metabolic and endocrine changes with emphasis on leptin. J. Dairy Sci. 86:1690-1706.

Rukkwamsuk, T., T. A. M. Kruip, and T. Wensing. 1999. Relationship between overfeeding and overconditioning in the dry period and the problems of high producing dairy cows during the postparturient period. Vet. Q. 21:71-77.

Rukkwamsuk, T., T. Wensing, and M. J. H. Geelen. 1998. Effect of overfeeding during the dry period on regulation of adipose tissue metabolism in dairy cows during the periparturient period. J. Dairy Sci. 81:2904-2911.

Sakai, T., M. Hamakawa, and S. Kubo. 1996. Glucose and xylitol tolerance tests for ketotic and healthy dairy cows. J. Dairy Sci. 79:372-377.

Sjaunja, L. O., L. Baerve, L. Junkkarinen, J. Pedersen, and J. Setälä. 1991. A Nordic proposal for an energy corrected milk (ECM) formula. Pages 156-157 in Performance Recording of Animals: State of the Art, 1990. P. Gaillon and Y. Chabert, ed. EAAP Publication no. 50, PUDOC, Wageningen, the Netherlands.

Tesfa, A. T., M. Tuori, L. Syrjälä-Qvist, R. Pösö, H. Saloniemi, K. Heinonen, K. Kivilahti, T. Saukko, and L.-A. Lindberg. 1999 The influence of dry period feeding on liver fat and postpartum performance of dairy cows. Anim. Feed Sci. Technol. 76:275-295.

Treacher, R. J., I. M. Reid, and C. J. Roberts. 1986. Effect of body condition at calving on the health and performance of dairy cows. Anim. Prod. 43:1-6.

Tuori, M., K. Kaustell, J. Valaja, E. Aimonen, E. Saarisalo, and P. Huhtanen. 2000. Rehutaulukot ja ruokintasuositukset [Feed Tables and Feeding Recommendations]. 3rd edition. Yliopistopaino, Helsinki, Finland.

Vazquez-Anon, M., S. Bertics, M. Luck, R. R. Grummer, and J. Pinheiro. 1994. Peripartum liver triglycerides and plasma metabolites in dairy cows. J. Dairy Sci. 77:1521-1528. 